\title{
The Nutritional Value of Sweet Potato Tubers [Ipomoea batatas (L.) Lamb.] Consumed by Infants and Children of Dani Tribe in Kurulu District, Baliem-Jayawijaya
}

\author{
Antonius Suparno ${ }^{1}$, Saraswati Prabawardani ${ }^{1} \&$ Andrew Bob Pattikawa ${ }^{2}$ \\ ${ }^{1}$ Department of Agrotechnology, Faculty of Agriculture, The University of Papua, Manokwari, West Papua, \\ Indonesia \\ ${ }^{2}$ Department of Agriculture, Animal Husbandry, and Plantation, Manokwari Regency, West Papua, Indonesia \\ Correspondence: Antonius Suparno, Department of Agrotechnology, Faculty of Agriculture, The University of \\ Papua, Jl. Gunung Salju, Amban-Manokwari, West Papua 98314, Indonesia. Tel: 62-853-5488-7556. E-mail: \\ anton.sprn@gmail.com
}

Received: December 7, 2015 Accepted: January 18, 2016 Online Published: February 15, 2016

doi:10.5539/jas.v8n3p64 URL: http://dx.doi.org/10.5539/jas.v8n3p64

\begin{abstract}
Sweet potato is an important staple food crop especially for the local people of Central Highlands Jayawijaya. There are many accessions that have always been maintained their existence to enrich the types of consumption. Traditionally, sweet potato accessions were grouped based on the utilization, such as for animal feed, cultural ceremonies, consumption for adults, as well as for children and infants. This study was aimed to analyze the nutritional value of sweet potatoes consumed by infants and children of the Dani tribe. Chemical analyses were conducted at the Laboratory of Post-Harvest Research and Development Center, Cimanggu, Bogor.

The results showed that each of 4 (four) sweet potato accessions, which were consumed by infants and children, had diverse nutrient levels. Accession Sabe showed the highest water content (72.56\%), vitamin $\mathrm{C}(72.71$ $\mathrm{mg} / 100 \mathrm{~g}), \mathrm{Fe}(11.85 \mathrm{mg} / 100 \mathrm{~g})$, and $\mathrm{K}$ levels $(130.41 \mathrm{mg} / 100$ grams). The highest protein content (1.44\%), fat $(1.00 \%)$, energy $(154.43 \mathrm{kkal} / 100$ gram), carbohydrate $(35.47 \%)$, starch $(30.26 \%)$, reducing sugar $(3.44 \%)$, riboflavin $(0.18 \mathrm{mg} / 100 \mathrm{~g})$, and vitamin A (574.40 grams IU/100) were produced by accession Manis. On the other hand, accession Saborok produced the highest content of ash $(1.32 \%)$, vitamin E $(28.30 \mathrm{mg} / 100 \mathrm{~g})$, and $\beta$-carotene (64.69 ppm). The highest level of crude fiber $(1.81 \%)$ and thiamin $(0.36 \mathrm{mg} / 100 \mathrm{~g})$ were produced by accession Yuaiken.
\end{abstract}

Keywords: Baliem-Jayawijaya, Dani tripe, nutrition, sweet potato

\section{Introduction}

Sweet potato is a nutritions food for humans and animals (Woolfe, 1992; Yamakawa \& Yoshimoto, 2001). It is a source of carbohydrate, rich in vitamin A and C (especially in yellow and orange flesh cultivars, but orange cultivars are much higher than yellow flesh cultivars), minerals, especially iron (Fe), phosphorus (P), and calcium $(\mathrm{Ca})$. Sweet potato also contains proteins and fats in low concentrations in the tubers, while the leaves are rich in protein, vitamins and minerals (Woolfe, 1992).

Sweet potato is the main staple food crops of the people in the Baliem Valley which constitute of $90 \%$ of the people diet. Baliem Valley is the largest valley in the highlands of Papua situated in Jawawijaya regency, located at 1650-1700 meters above sea level in altitude and geographically positioned at $138^{\circ} 30^{\prime}$ longitude east (LE) BT $-139^{\circ} 30^{\prime}$ LE, $34^{\circ} 0^{\prime}$ longitude south (LS) $-42^{\circ} 0^{\prime}$ LS. This valley stretches from west to east with $60 \mathrm{~km}$ and 16 $\mathrm{km}$ in length and width, respectively (Widyastuti, 1994). As the crop plays an important role, sweet potato cultivation by Dani people has reflected the energy, time and attention which are devoted to meet their basic needs of food. The local people of Baliem valley have been adapted and relied on sweet potato as a staple food for a quite long time. This has been supported by suitable ecological, cultural and biophysical factors in maintaining the cultivation of this crop.

In Kurulu District of the Baliem Valley, there are 43 types of sweet potato accessions consumed for infants, children, adults, livestock, pigs, and utilized for local ceremonies (Logo, 2011). It was also found a sweet potato 
accession which is only used as leafy vegetable. Grouping the accession of sweet potatoes into many aspects of utilization is related to indigenous knowledge of the Dani local communities. Until recently, research on grouping in the basic of nutritional content including the utilization of sweet potato consumed by infants and children have not been scientifically conducted.

This study aimed to determine the nutritional value of four sweet potato accessions which are mainly consumed by infants and children of the Dani tribe in Kurulu District Baliem-Jayawijaya. Results of this study are expected to provide scientific information on the nutritional value of the sweet potato accessions, in order to provide a guidance on food intake for the provision of infants and children. In addition, this study is also expected to be a source of genetic information for sweet potato breeding program.

\section{Materials and Methods}

The research was carried out for 3 months starting from September to November 2011. Samples were taken from farmer's garden of sweet potato in Kurulu District, Baliem-Jayawijaya (Figure 1). Analysis of nutrient levels was carried out in the Laboratory of The Center for Research and Post-harvest Development of the Ministry of Agriculture, Cimanggu, Bogor, West Java.

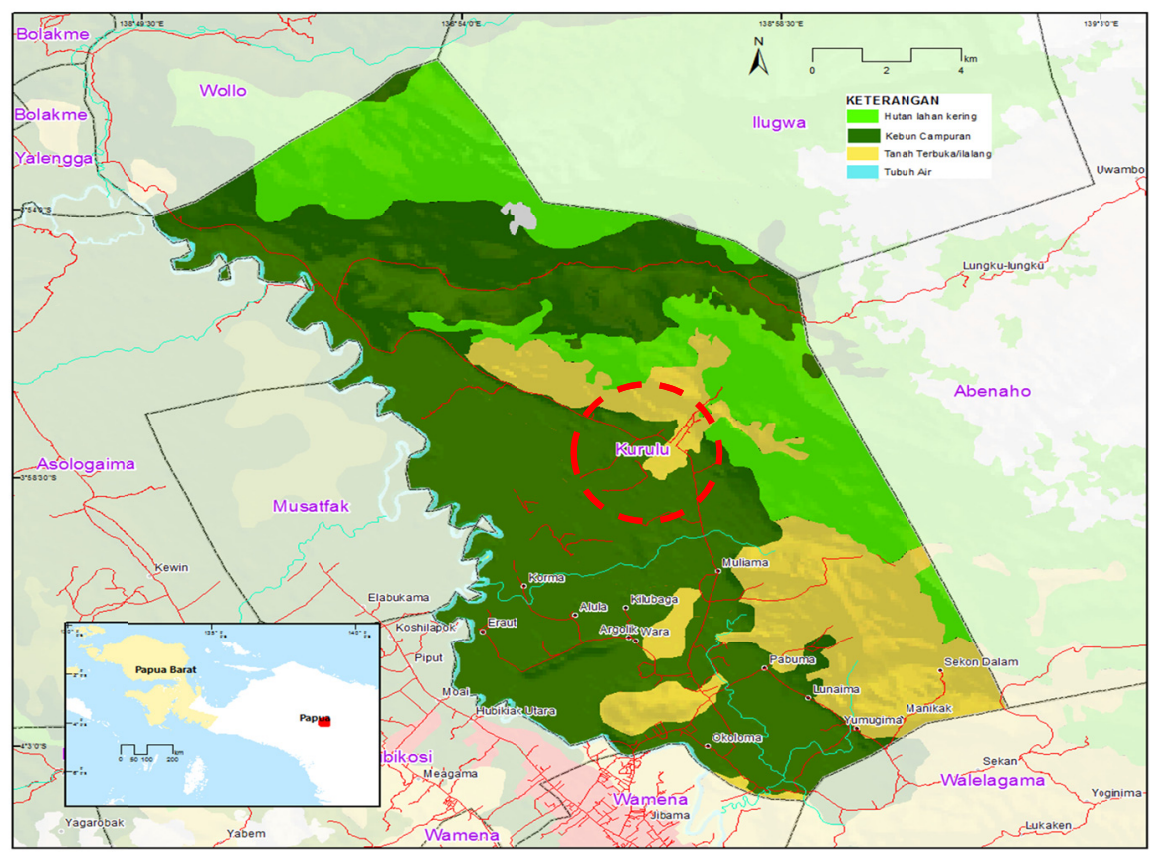

Figure 1. Location where sweet potato samples were taken

Descriptive method with field observation techniques was applied to determine the dominant accessions or accessions which are widely used by the community, and followed by laboratory analysis. Afterwards, four dominant accessions used for consumption of infants and children were selected. For the purpose of nutrient analysis, sweet potato tubers were taken from harvested plants. Tubers were cleaned from soil and other debris, then wrapped and sent to the laboratory. Sweet potato tuber samples were analysed in accordance to standard procedures established by AOAC (1990) which consisted of water content, ash, protein, fat, crude fiber, energy, carbohydrates, starch, sugar reduction, thiamin, riboflavin, vitamin $\mathrm{A}$, vitamin $\mathrm{C}$, vitamin $\mathrm{E}, \beta$-carotene, Fe content, and $\mathrm{K}$ in a dry weight bases.

\section{Results and Discussion}

Tuber nutrients levels of four sweet potato accessions consumed by infants and children are presented in Table 1 . The highest water content $(72.56 \%)$ is found in the Sabe accession. This water content is lower than the results studied by Hartoyo (2004) which was $83.3 \%$. This different is due to genetic as well as environmental factors. Tubers with high water content are essential for infants and children as facilitate the digestive process. Sweetpotato accession with low tuber water content, but having high nutrient levels can be easily consumed by infants and children, through the process of steaming or boiling. 
Table 1. Water content, ash, protein, fat, crude fiber and energy of four sweet potato tuber accessions consumed by infants and children

\begin{tabular}{lllllll}
\hline \multirow{2}{*}{ Accession } & \multicolumn{7}{c}{ Nutriens levels } \\
\cline { 2 - 6 } & Water (\%) & Ash (\%) & Protein $(\%)$ & Fat (\%) & Crude fiber (\%) & Energy $\left(\mathrm{Kcal}_{\left.100 \mathrm{~g}^{-1}\right)}\right.$ \\
\hline Saborok & 61.26 & 1.32 & 1.18 & 0.95 & 1.06 & 154.43 \\
Sabe & 72.56 & 0.87 & 1.09 & 0.83 & 1.31 & 110.43 \\
Yuaiken & 62.83 & 1.16 & 0.91 & 0.85 & 1.81 & 148.29 \\
Manis & 61.03 & 1.06 & 1.44 & 1.00 & 1.21 & 153.94 \\
\hline
\end{tabular}

The highest ash content contained in the Sabrok accession is $1.32 \%$. Barlina (1996) found that ash content of sweet potato tubers ranged from 2.92 to $4.33 \%$. Ash is the residual products of organic matter combustion. Thus, ash is a good source of minerals (Suarni \& Firmansah, 2005), consisting of various kinds of minerals from either organic salts (oxalat acetate, pectat) or inorganic salts (phosphates, carbonates and sulfates). Minerals are required by human body in small amounts, but they play an important role in metabolic processes. However, high ash content can also be resulted from an enzymatic reaction which causing decreased levels of starch (Suarni \& Firmansah, 2005). High ash content is less preferred on the flour industry because it tends to give dark color of the product. The lower the ash content in flour products, the better the color of final product and the stability of flour (Ambarsari et al., 2009).

The highest protein content resulted from the Manis accession is $1.44 \%$. This is similar to the results of Hartoyo (2004) that was $1.43 \%$, but lower than the research done by Areghoere and Tofinga (2004) on other sweet potato cultivars which was $6.8-8.2 \%$. While Saraswati et al. (2013) observed higher protein content which reached $4.6 \%$ of local sweet potato cultivar (Ungu) or in average across cultivars (local and introduced) was 3\% in the Highland of Papua and West Papua. Sweet potatoes are rich in carbohydrates but the average of protein content is low in tubers. Therefore, to meet the requirement of protein, the balance between the consumption of sweet potato as a source of carbohydrates and other plants as a source of protein is highly recommended for the local communities, especially for infants, children, and adults because protein is one of the macro nutrients that needed by human bodies. The main function of protein is as a growth substance during the growth period. From infancy to adolescence, the need of protein intake is greater than during adulthood and elderly. In adulthood and elderly, the function of protein is to maintain the body's tissues and replace damaging cells.

The highest level of fat is found in the tubers of Manis accession (1.00\%) which was in the similar ranges to the finding of Saraswati et al. (2013). However, this result is higher than the result derived by Hartoyo (2004) that fat content of sweet potato tuber was $0.17 \%$. Islam (2006) suggests that fat content in sweet potato tubers ranged between $0.06 \%-0.48 \%$. Fats serve as energy reserves, producing essential fatty acids and as a solvent of vitamins.

The highest crude fiber content found in Yuriken accession is $1.81 \%$, which was higher than the result of the research conducted by Hartoyo (2004) that was $1.6 \%$. Although crude fiber does not contain essential nutrients, its function as a regulator of food excretion is very substantial. According to Piliang (2006) crude fiber helps in acceleration of food remnants excretion through the digestive tract. Selection of accession with high content of crude fiber for infants and children is possible because it serves to preserve and protect the baby's and children digestive system.

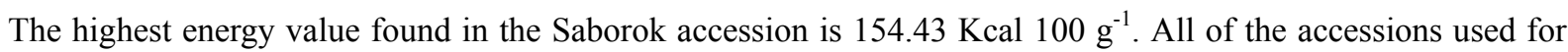
infants and children consumption are higher in energy value than the research conducted by Hartoyo (2004) that

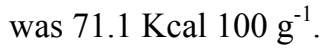

Manis accession has the highest level of carbohydrate (35.47\%), starch (30.26\%), reduced sugar (3.44\%),

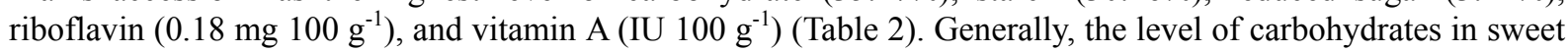
potato tubers is approximately $27.9 \%$ (Dirjen Kesehatan, 2005). Carbohydrate serves as an energy source for the growth of infants and children. Carbohydrate of sweet potato tubers constitute of low glycemic index (54). According to Allen et al. (2012), dehydrated and raw sweetpotato flesh had a low glycemic index ( $41 \pm 4.0$ and $32 \pm 3.0$, respectively). In addition, steamed skin, baked skin, and dehydrated flesh did not have a statistically different glycemic index from raw sweet potatoes (Allen et al., 2012). Low glycemic index tend to slow the rate of glucose absorption, therefore maintaining the low level of blood glucose. 
Table 2. Contents of carbohydrates, starch, reduced sugar, thiamin, riboflavin and vitamin A of four sweet potato tuber consumed by infants and children

\begin{tabular}{llllll}
\hline \multirow{2}{*}{ Accession } & \multicolumn{5}{c}{ Nutritional Content } \\
\cline { 2 - 6 } & Carbohydrates (\%) & Starch (\%) & Reduced sugars (\%) & Thiamin $\left({\left.\mathrm{mg} 100 \mathrm{~g}^{-1}\right)}^{\text {Riboflavin }\left(\mathrm{mg} \mathrm{g}^{-1}\right)}\right.$ \\
\hline Saborok & 35.29 & 29.71 & 2.21 & ud & $7.65\left(10^{-3}\right)$ \\
Sabe & 24.65 & 20.41 & 2.48 & ud & $2.53\left(10^{-3}\right)$ \\
Yuaiken & 34.25 & 28.93 & 2.82 & 0.36 & 0.07 \\
Manis & 35.47 & 30.26 & 3.44 & ud & 0.18 \\
\hline
\end{tabular}

Note. $\mathrm{ud}=$ undetected.

Reduced sugars are sugars with the ability to be reduced because the existence of aldehyde or free cetone group. The compounds which oxidize or act as reducing agents are oxidizing metals such as $\mathrm{Cu}$ (II). Vitamin B1, also known as thiamin plays an important role in maintaining healthy skin and helping to convert carbohydrates into energy needed by the body. Vitamin B1 also helps to metabolize proteins and fats. If there is a deficiency of vitamin B1, the skin will a dry and scaly, suffering from beri-beri disease, gastrointestinal and cardiovascular disorders, and disrupting the nervous system.

Vitamin B2 (riboflavin) plays a crucial role in the body's metabolism. It is also considered as one component of co-enzimflavin mononucleotide (flavin mononucleotide, FMN) and flavin adenine dinucleotide (adenine dinucleotide, FAD). Both of these enzymes play an important role in the regeneration of energy for the body through the respiration process. This vitamin is also helpful in the formation of steroid molecules, red blood cells, and glycogen, as well as supporting the growth of various organs, such as skin, hair, and nails.

The highest levels of vitamin E (28.30 mg $\left.100 \mathrm{~g}^{-1}\right)$ and $\beta$-carotene (64.69 ppm) are found in Saborok accession, whereas Sabe accession has the highest levels of vitamin C (72.71 mg $\left.100 \mathrm{~g}^{-1}\right), \mathrm{Fe}\left(11.85 \mathrm{mg} 100 \mathrm{~g}^{-1}\right)$, and K (130.41 mg $100 \mathrm{~g}^{-1}$ ) (Table 3).

Table 3. Contents of vitamin $\mathrm{C}$, vitamin $\mathrm{E}, \beta$-carotene, $\mathrm{Fe}$, and $\mathrm{K}$ of sweet potato tubers for infants and children consumption

\begin{tabular}{|c|c|c|c|c|c|}
\hline \multirow{2}{*}{ Accession } & \multicolumn{5}{|c|}{ Nutritional Contens } \\
\hline & Vitamin C (mg $\left.100 \mathrm{~g}^{-1}\right)$ & Vitamin E (mg $\left.100 \mathrm{~g}^{-1}\right)$ & $\beta$-carotene (ppm) & $\mathrm{Fe}\left(\mathrm{mg} 100 \mathrm{~g}^{-1}\right)$ & $\mathrm{K}\left(\mathrm{mg} 100 \mathrm{~g}^{-1}\right)$ \\
\hline Saborok/light yellow & 25.44 & 28.30 & 64.69 & 4.21 & 87.11 \\
\hline Sabe/purple & 72.71 & 18.76 & 38.81 & 11.85 & 130.41 \\
\hline Yuaiken/white & 67.22 & 11.24 & 52.44 & 4.52 & 123.86 \\
\hline Manis/light yellow & 20.47 & 19.68 & 62.98 & 10.50 & 95.16 \\
\hline
\end{tabular}

Vitamin C (ascorbic acid) brings many beneficiaries for health. Vitamin $\mathrm{C}$ also acts as a collagen-forming compound which is an important protein that constitute skin tissue, joints, bones, and other supported tissues. Vitamin $\mathrm{C}$ is natural antioxidant that can counteract free radicals produced from pollution in the surrounding environment. In association with its ability to counteract free radicals, vitamin $\mathrm{C}$ is able to lower the rate of mutation in the body so it prevent the risk of various degenerative diseases, such as cancer. In addition, vitamin $\mathrm{C}$ plays a role in maintaining the shape and structure of various tissues in the body, such as muscles. This vitamin $\mathrm{C}$ also plays a role in wound coverage when there is bleeding and provide more protection from infection caused by pathogenic microorganisms. Through this mechanism, vitamin $\mathrm{C}$ plays a role in maintaining physical fitness and helping to prevent various kinds of diseases. Deficiency of vitamin $\mathrm{C}$ can also resulting bleeding gums and pain in the hinges. In contrast, excessive accumulation of vitamin $\mathrm{C}$ in the body can generate kidney stones, gastrointestinal disorders, and destructed of red blood cells.

Vitamin E plays a role in maintaining the health of various tissues in the body, ranging from skin tissue, eyes, red blood cells to the liver. This vitamin can also protect the lungs from air pollution, as it is strongly related to the work of vitamin $\mathrm{E}$ in the body as a natural antioxidant. 
Beta-carotene is one of precursor of vitamin A other than $\alpha$-carotene and $\beta$-criptoxanthin and $\beta$-carotene compounds, which is a primary component of pro-vitamin A existing in most food containing carotenoid compounds (van Jaarsveld et al., 2005). Betha-carotene plays an important role in maintaining the health of sight senses (Hashim \& Yusuf, 2008). The analysis result, showed that the highest levels of beta-carotene produced by Sabe accession (388.10 ppm). Sabe accession is the orange tuber flesh cultivar. According to Van Jaarsveld et al., (2005) the sources of pro-vitamin A are fruits and vegetables which are yellow and orange, and dark green leafy vegetables. Orange-fleshed sweet potato tuber is one of beta carotene source (Eluagu \& Oniwamo, 2010), which contains 20-30 times more $\beta$-carotene than brown rice (Woolfe, 1992). The levels of $\beta$-carotene contained in the tubers orange-fleshed sweet potato is higher than the yellow and white tuber flesh colour (Sebuliba et al., 2001). The results of chemical analysis by the Asian Vegetable Research and Development Centre (AVRDC), revealed that sweet potato tubers contain beta carotene ranged from 0-21 mg $100 \mathrm{~g}^{-1}$ fresh weight (Villareal \& Lo, 1983). According to Woolfe (1992), orange and yellow sweet potato tubers contains $\beta$-carotene up to $4,000 \mathrm{mg} 100 \mathrm{~g} \mathrm{~g}^{-1}$ (in the basic of fresh tuber), while the content of $\beta$-carotene in white-fleshed sweet potato tubers is less than 70 $\mathrm{mg} 100 \mathrm{~g}^{-1}$. The intensity of the orange color is produced by carotenoids (Ameny \& Wilson, 1997) which is a pro-vitamin A and also act as antioxidants to fight free radical.

Iron salt is a very important element in hemoglobin formation, in which colour substance elements contained in the red blood that is useful for transporting oxygen and $\mathrm{CO}_{2}$ throughout body. Haemoglobin is the bond between protein, iron salts, and colour substance elements. Sixty percent of the iron in the human body is found in hemoglobin, and the human body uses iron salts effectively. When the red blood is broken down, the released iron salt will be taken over by the body to produce new hemoglobins.

Potassium is essential mineral for the proper function of all cells, tissues, and organs in the human body. Along with sodium, chloride, calcium, and magnesium, potassium serves is maintaining electrolyte balance in the body. In addition, potassium plays an important role in maintaining heart function, skeletal muscle contraction, and digestive function.

\section{Conclusions}

The variety of sweet potato cultivated in Kurulu District, Baliem-Jayawijaya has a great potential as nutritionaly food, particularly carbohydrate, minerals $(\mathrm{Fe}$ and $\mathrm{K})$, vitamin $(\mathrm{B}, \mathrm{C}, \mathrm{E})$ and $\beta$-carotene in promoting and enhancing the growth of infants and children.

The diverse levels of nutrient content are important genetic resources for breeding strategy in sweet potato development in order to obtain a promising type of sweet potato. Hence, preservation of various accessions require important attention to support food security and food diversification.

\section{Acknowledgements}

Our great gratitude goes to Laboratory of The Center for Research and Post-harvest Development of the Ministry of Agriculture, Cimanggu, Bogor, West Java, the Government of Papua Provincy, Jayawijaya Regency, Kurulu District, and everyone who supported this research.

\section{References}

Allen, J. C., Corbitt, A. D., Maloney, K. P., Butt, M. S., \& Truong, V. D. (2012). Glycemic Index of Sweet Potato as Affected by Cooking Methods. The Open Nutrition Journal, 6, 1-11. http://dx.doi.org/10.2174/1874288201206010001

Ambarsari, I., Sarjana, \& Choliq, A. (2009). Rekomendasi Dalam Penetapan Standar Mutu Tepung Ubi Jalar. Balai Pengkajian Teknologi Pertanian, Jawa Tengah.

Ameny, M. A., \&Wilson, P. W. (1997). Relationsip between Hunter Color Value and $\beta$-Carotene Contents in White Flesh African Sweet Potatoes (Ipomoea batatas Lam.). J. Sci. Food and Agric., 73, 301-306. http://dx.doi.org/10.1002/(SICI)1097-0010(199703)73:3<301::AID-JSFA726>3.0.CO;2-Z

Areghoere, E. M., \& Tofinga, M. (2004). Influence of type of mulch material on distribution and accumulation of nutrients in sweet potato (Ipomoea batatas) in Samoa. J. of Agri. and Biol., 3, 520-524. Retrieved from http://www.eurekamag.com/research/004/205/004205721.php

Assocciation of Official Analytical Chemist (AOAC). (1990). Official Methods of Analysis of the Assocciation of Official Analytical Chemist (15th ed.). Washington DC.

Barlina, R. (1996). Pengembangan Berbagai Produk Pangan Dari Daging Buah Kelapa Hibrida. Balai Penelitian Tanaman Kelapa dan Palma Lain. Manado-Sulawesi Utara. 
Dirjen, K. (2005). Departemen Kesehatan Republik Indonesia. Badan Ketahanan Pangan Nasional (BKPN).

Eluagu, E. N., \& Onimawo, I. A. (2010). Effect of Processing on the Mineral Composition and Antinutritional Factors of Orange Fleshed Sweet Potato (Ipomoea batatas L. Lam.) Flours. Electronic Journal of Environmental, Agricultural and Food Chemistry, 9(6), 1000-1005. Retrieved from http://www.cabdirect. org/abstracts/20103324692.html;jsessionid=C8D2846A6E72B44D91F003BA833ABE21

Hartoyo, T. (2004). Olahan dari Ubi Jalar. Trubus Agrisarana, Surabaya.

Hasyim, A., \& Yusuf, M. (2008). Ubijalar Kaya Antonsianin, Pilihan Pangan Sehat. Sinar Tani Edisi 20. Agustus 26, 2008.

Islam, S. (2006). Sweetpotato Leaf: Its Potential Effect on Human Health and Nutrition. J. Food Sci., 71, 13-21. http://dx.doi.org/10.1111/j.1365-2621.2006.tb08912.x

Logo, O. (2011). Deskripsi Morfologi Beberapa Jenis Ubi Jalar (Ipomoea batatas (L.) Lam.) Berdasarkan Pola Pemanfaatan Oleh Suku Dani di Distrik Kurulu Kabupaten Jayawijaya (Skripsi). Universitas Negeri Papua. Manokwari.

Piliang, W. G. (2006). Fisiologi Nutrisi 2. Penerbit IPB Press, Bogor. Retrieved from http://www.mitraahmad.net/buku-fisiologi_nutrisi_jilid_2_ipb-8223.html

Saraswati, P., Soplanit, A., Syahputra, A. T., Kossay, L., Muid, N., Ginting, E., \& Lyons, G. (2013). Yield Trial and Sensory Evaluation of Sweetpotato Cultivars in Highland Papua and West Papua Indonesia. Journal of Tropical Agriculture, 51(1-2), 74-83.

Sebuliba, J. M., Nsubuga, E. N., \& Muyonga, J. H. (2001). Potential of Orange and Yellow Fleshed Sweetpotato Cultivars for Improving Vitamin A Nutrition in Central Uganda. African Crop Science Journal, 9(10), 309-316. http://dx.doi.org/10.4314/acsj.v9i1.27653

Suarni, \& Firmansyah, I. U. (2005). Beras jagung: Prosesing dan nutrisi sebagai bahan pangan pokok (pp. 393-398). Prosiding Seminar dan LokakaryaNasional Jagung. Makassar.

Van Jaarsveld, P. J., Faber, M., Tanumihardjo, S. A., Nestle, P., Lombard, C. J., \& Benade, A. J. S. (2005). $\beta$-Carotene Rich Orange Fleshed Sweet Potato Improves the Vitamin A Status of Primary School Children Assessed with the Modified-Relative-Dose-Response Test. American Journal of Clinical Nutrition, 81(5), 1080-1087.

Villareal, R. L., \& Lo, H. F. (1983). Utilization of Sweet Potato Germplasm by Plant Breeders. Philippines Journal of Crop Science, 8(3), 113-118. Retrieved from http://www.cabi.org/gara/FullTextPDF/2009/20093019523.pdf

Widyastuti, C. A. (1994). Peranan Wanita Suku Dani Dalam Mempertahankan Kelangsungan Ubijalar Sebagai Makanan Pokok Di Kabupaten Jayawijaya, Irian Jaya (Studi kasus Desa Asotipo, Kimbim, dan Malagai). Edisi khusus Balittan Malang, 3, 353-360.

Woolfe, J. A. (1992). Sweet Potato: An Untapped Food Resource. Cambridge University Press. Cambridge, United Kingdom. http://dx.doi.org/10.12691/ajfst-2-4-1

Yamakawa, O., \& Yoshinoto, M. (2001). Sweet potato as food material with physiological functions. Acta Hort. (ISHA), 583, 179-185. http://dx.doi.org/10.17660/ActaHortic.2002.583.20

\section{Copyrights}

Copyright for this article is retained by the author(s), with first publication rights granted to the journal.

This is an open-access article distributed under the terms and conditions of the Creative Commons Attribution license (http://creativecommons.org/licenses/by/3.0/). 